\title{
Miliolinella subrotunda (Montagu), a miliolid foraminifer building large detritic tubes for a temporary epibenthic lifestyle
}

\author{
A.V. Altenbach, T. Heeger, P. Linke, M. Spindler and A. Thies \\ Sonderforschungsbereich 313, Universität Kiel, Olshausenstraße 40, 2300 Kiel, Germany
}

(Received March 21, 1992; revision accepted August 1, 1992)

\begin{abstract}
Altenbach, A.V., Heeger, T., Linke, P., Spindler, M. and Thies, A., 1993. Miliolinella subrotunda (Montagu), a miliolid foraminifer building large detritic tubes for a temporary epibenthic lifestyle. In: M.R. Langer (Editor), Foraminiferal Microhabitats. Mar. Micropaleontol., 20: 293-301.
\end{abstract}

Live observations, cytological characteristics and biometrical measurements on Miliolinella subrotunda (Montagu, 1803) sampled from the northern and southern Atlantic Ocean are presented. $M$. subrotunda facultatively constructs a long, detritic tube lifting the test several millimeters above the sediment surface. A thickened conical base anchors the construction on the sediment surface and a long, flexible tube protrudes into the velocity profile of the bottom currents. The miliolid test is placed on top, surrounded by the uppermost part of the tube. This construction allows the organisms to feed in the particle stream above the sediment surface. In comparison to species living in and on the surface sediments, $M$. subrotunda apparently shows higher nutritional values in food ingested and larger amounts of reserve substances. Characteristics of the shape and structure that reduce drag on the tubes include a broadened conical base, a flexible tube, and a rounded top. From biometrical measurements it is concluded, that the tubes are constructed over a short period of their ontogeny.

\section{Introduction}

Benthic foraminifera utilize a variety of adaptations to access water levels with faster currents, such as settling on stones, algae or macrofaunal hardparts protruding from the sediment surface into the water column. Several agglutinated foraminifera show test constructions raised from the sediment (Lipps, 1983; Altenbach et al., 1988) and one rotaliid is known to use sponge spicules to extend the range of pseudopodial activities (Lutze and Altenbach, 1988). In the case of miliolids, the production of detritic cysts covering the test and part of the surrounding area is well de-

Correspondence to: A.V. Altenbach, Sonderforschungsbereich 313, Universität Kiel, Olshausenstraße 40/60, $2300 \mathrm{Kiel}$, Germany. scribed (Rhumbler, 1936). In the present case we focus on a special type of organic, tubiform cyst on which the test is elevated off the sediment surface.

\section{Material and methods}

During cruises Meteor 7, Polarstern Ark III/ 3 and Poseidon 141 multicorer and grab samples were taken in the northern and southern Atlantic Ocean for studies of deep-sea benthic foraminifera (Table 1). At these locations, visual and microscopic observations of the sediments revealed benthic foraminifera on top of agglutinated tubes extending up from the sediment surface. Live organisms were recovered with needle tweezers from the sediment, covered in seawater, examined under a binocular microscope and preserved for sub- 
TABLE 1

Station list

\begin{tabular}{lrllll}
\hline $\begin{array}{l}\text { Cruise } \\
\text { no. }\end{array}$ & Sample Lat. & Long. & $\begin{array}{l}\text { wd } \\
\text { (m) }\end{array}$ & $\begin{array}{l}\text { Sampling } \\
\text { gear }\end{array}$ \\
\hline $\begin{array}{lrlll}\text { Meteor } 7 \\
\text { Poseidon } 141\end{array}$ & 533 & $67^{\circ} 44^{\prime} 1 \mathrm{~N}$ & $05^{\circ} 55^{\prime} 6 \mathrm{E}$ & 1243 & muc, bg \\
$\begin{array}{l}\text { Poseidon } 141 \\
\text { Polarstern }\end{array}$ & 1121 & $67^{\circ} 39^{\prime} 1 \mathrm{~N}$ & $05^{\circ} 46^{\prime} 9 \mathrm{E}$ & 1419 & muc, bg \\
\hline
\end{tabular}

$\mathrm{wd}=$ water depth; muc $=$ multicorer; $\mathrm{bg}=$ boxgrab; $\mathrm{vg}=$ Van Veen grab.

sequent studies (formaldehyde $2.5 \%$, or methanol including 2\% Rose Bengal). For transmission electron micrographs (TEM), foraminifers were fixed in seawater buffered with $2.5 \%$ glutaraldehyde and postfixed in $1 \%$ osmium tetroxide, decalcified with $0.2 \mathrm{M}$ EDTA, dehydraded in a graded alcohol series and embedded in ERL (Heeger, 1990). Sections were cut by a diamond knife and stained with $1 \%$ uranyl acetate and $0.5 \%$ lead citrate. TEM's were taken with a Zeiss 109 operated at $80 \mathrm{keV}$. The scanning electron micrographs (SEM) were taken with a SEMCO NANOLAB 7 (Institut für Mikrobiologie/Kiel) and a Cambridge Stereoscan S-10 (Geologisch-Paläontologisches Institut/Kiel ). A computer based image analyser (Thomsen, 1991) was used for biometrical measurements of the morphology of the tests, tubes, and size distribution of particles attached to the tubes as derived from SEM close-ups. All specimens were measured intact. In order to minimize errors, the results are based on at least 5 to 10 measurements made from different persprectives. All statistical data were computed using the ST-Statistik software package (SciLab Ltd., Hamburg).

\section{Life position and morphology}

Tube constructions extending from the sediment surface into the water column were visible to the naked eye in samples taken by multicorers. On undisturbed sediment surfaces and in clear water, this was possible even in samples from box corers and grab samplers. A del- icate light brown stalk extended upward from the sediment surface and swayed slightly with the water movement. Closer examination revealed that the tube had the same consistency and coloring as the sediment and that the tip of the tube was expanded, covering the entire test (Plate I, 2 and 3). The conical base was anchored to the sediment; under the binocular microscope, delicate organic threads on the conical base were visible during removal of the organism from the sediment. A small portion of sediment in the immediate vicinity was removed as well. Miliolinella subrotunda (Plate I, 1 and 4 ) was positioned vertically on the uppermost end of the cylindrical tube, the aperture facing upward (Plate I, 3). A plug was formed by the cytoplasm and detritus in front of the aperture (Plate I, 5) and a few pseudopods extended to the uppermost portion of the agglutinated tube on the base of the test.

The total lengths of the 12 constructions measured (Fig. 1) range from 1015 to 6389 $\mu \mathrm{m}$, and the range of the mean diameter of the tubiform parts is 63 to $178 \mu \mathrm{m}$. Length and diameter of the tests on top of the tubes ranges from 105 to $628 \mu \mathrm{m}$ and from 127 to $507 \mu \mathrm{m}$, respectively. The average diameter of each tube remains constant (with some random deviation, see Table 2) from the top of the conical base up to the base of the test, as calculated from measures placed stepwise at 6 to 26 positions on each tubiform part. Despite wide variability among individuals, the measurements are all significantly correlated with each other (Table 2). Logarithmic scaling, such as allometric growth functions (Von Bertalanffy, 1960 ), might increase the correlation of biometric measures taken; however, this needs to be tested on a greater number of samples.

In SEM close-ups, particles on the outer wall of the tube of specimen 1 (Table 2) were measured at 15 positions placed from the conical base of the tube up to the top of the test. Clay particles and fragments of coccoliths and diatoms were most common, while sponge spines and quartz grains were rare. However, the ma- 

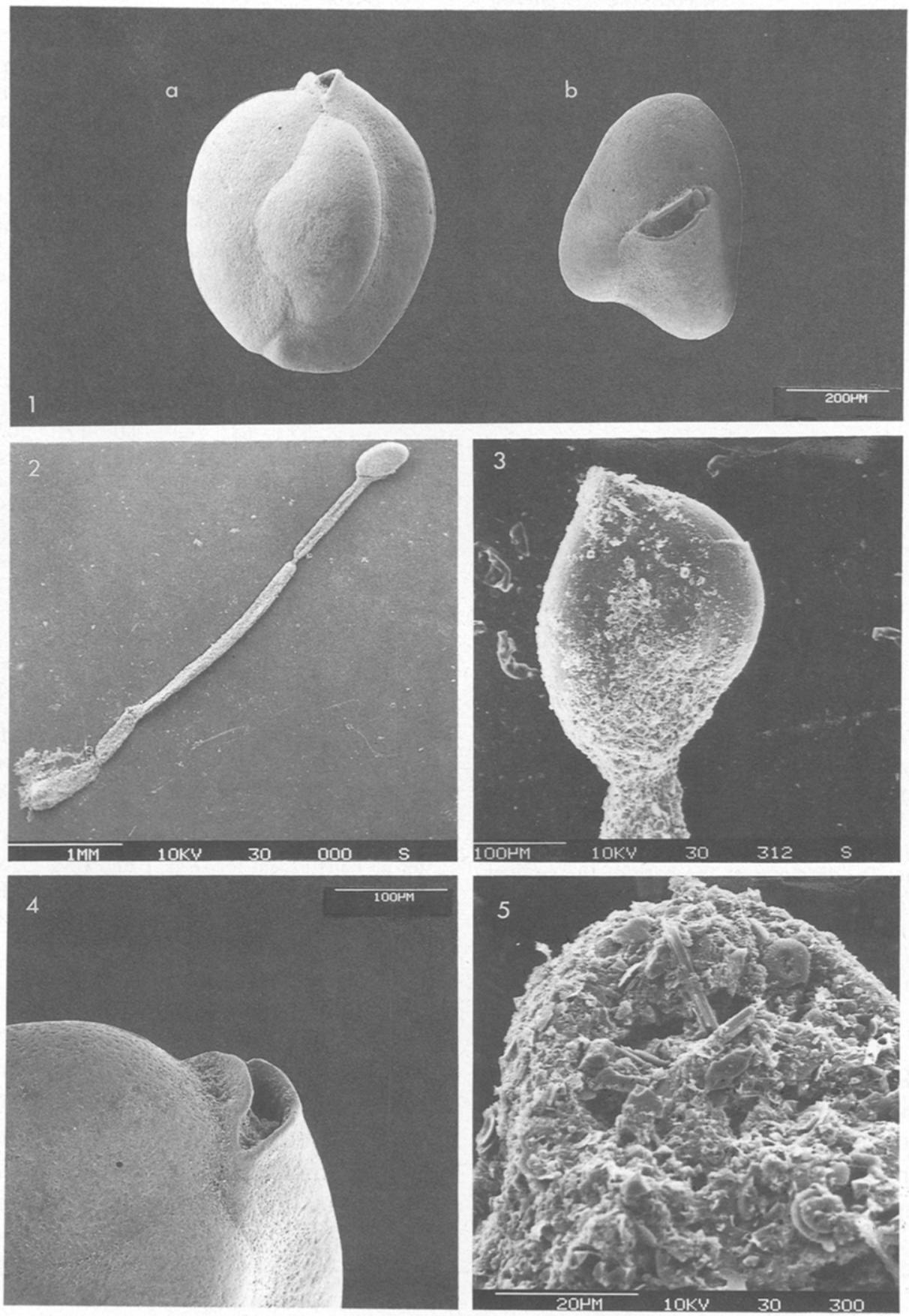

\section{PLATE I}

Test and tube structure of Miliolinella subrotunda.

1. Test of Miliolinella subrotunda (a) lateral view, (b) top view.

2. Individual with complete tube structure. The collapsed tube is an artifact of the preservation.

3. Lateral view of the test. The detritic cover is partially removed due to sample treatment.

4. Aperture without detritic cover.

5. Aperture covered with aggregates of undigestable particles, e.g. coccoliths, diatom fragments and other silicate structures. 


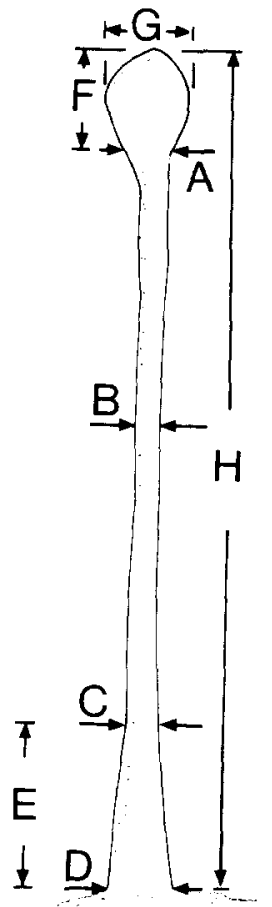

Fig. 1. Schematic life position of $M$. subrotunda (see Plate I). The measured lengths and diameters are as follows: $A=$ tube diameter at test base; $B=$ average tube diameter as determined by stepwise measurements from the top of the cone to the base of the test; $C=$ tube diameter at the top of the cone; $D=$ diameter at the base of the conical base segment; $E=$ height of conical base segment; $F=$ test length including agglutinated cover; $G=$ test width including agglutinated cover; $H=$ total length of tube from conical base to top of test.

jority of aggregates in the size range of a few microns or smaller remained unidentified. The mean sizes of particles were distributed nearly evenly over the entire tube, except for the youngest, uppermost portion, where coarser,
TABLE 2

Biometric measurement of 12 specimens of Miliolinella subrotunda. Values given in micrometers. $A=$ tube diameter at test base. $B=$ average tube diameter as determined by stepwise measurements from the top of the cone to the base of the test. $\mathrm{C}=$ tube diameter at the top of the cone. $\mathrm{D}=$ diameter at the base of the conical base segment. $E=$ height of conical base segment. $F=$ test length including agglutinated cover. $G=$ test width including agglutinated cover. $\mathrm{H}=$ total length of tube from conical base to top of test. For abbreviations see also Fig. 1

\begin{tabular}{lrlllllll}
\hline Specimen & A & B & C & D & E & F & G & H \\
\hline 1 & 243 & 178 & 332 & 525 & 869 & 628 & 507 & 6398 \\
2 & 77 & $68^{*}$ & $63^{*}$ & 60 & 171 & 202 & 127 & 2374 \\
3 & 128 & $124^{*}$ & $131^{*}$ & 155 & 276 & $192^{*}$ & 266 & 3987 \\
4 & 79 & $71^{*}$ & $95^{*}$ & 125 & 241 & $124^{*}$ & 205 & 3126 \\
5 & 88 & $82^{*}$ & 99 & 300 & 346 & $115^{*}$ & $206^{*}$ & 2711 \\
6 & $77^{*}$ & $65^{*}$ & $70^{*}$ & $77^{*}$ & 125 & $106^{*}$ & 145 & 1015 \\
7 & 80 & $74^{*}$ & 113 & 150 & 211 & 154 & $238^{*}$ & 2590 \\
8 & 94 & $86^{*}$ & $110^{*}$ & 214 & 396 & $162^{*}$ & 228 & 3554 \\
9 & 82 & $70^{*}$ & 73 & 58 & 197 & 105 & $250^{*}$ & 1950 \\
10 & 82 & $63^{*}$ & - & - & - & 124 & $170^{*}$ & 1345 \\
1 & 123 & $103^{*}$ & 180 & 302 & 345 & 206 & $375^{*}$ & 3614 \\
12 & 85 & $91^{*}$ & 125 & $153^{*}$ & 238 & 123 & $171^{*}$ & 2550
\end{tabular}

Standard deviation for column B calculated from measures placed stepwise at 6 to 26 positions on each tube. Conical tube segment of specimen no. 10 torn along the length of the tube. The linear correlation coefficient of each pair of variables is $r>0.82(P<0.05$ to $P<0.01) ; t$-test $P$-values less than 0.05 for all pairs except for D vs. F and E vs. G. Mean standard deviation of multiple measurements from different angles of view greater 3\%, maximum deviation greater $10 \%\left(^{*}\right)$.

and thus identifiable particles, were rare (Plate $I, 3)$. The texture and coarseness found in this uppermost portion was also present on the inner wall of the tube. The thickness of the tubes wall was not measured in detail; however, no distinct increase or decrease was observed from the conical base to the test. If opposite sides of

\section{PLATE II}

TEM micrographs of different chambers from Miliolinella subrotunda

1. The cytoplasm of a young chamber is filled with food vacuoles containing coccale and thecate algae. The material is freshly incorporated and hardly digested, $\mathrm{bar}=2 \mu \mathrm{m}$.

2. The degeneration of chloroplasts indicates the beginning of digestion, bar $=2 \mu \mathrm{m}$.

3. Combined micrographs of different chambers showing cryptoquinqueloculine organisation on an ultrastructure level. Younger chambers contain ingested food particles. In older chambers the number of lipid vesicles increases while the number of food vacuols decreases, bar $=10 \mu \mathrm{m}$. 

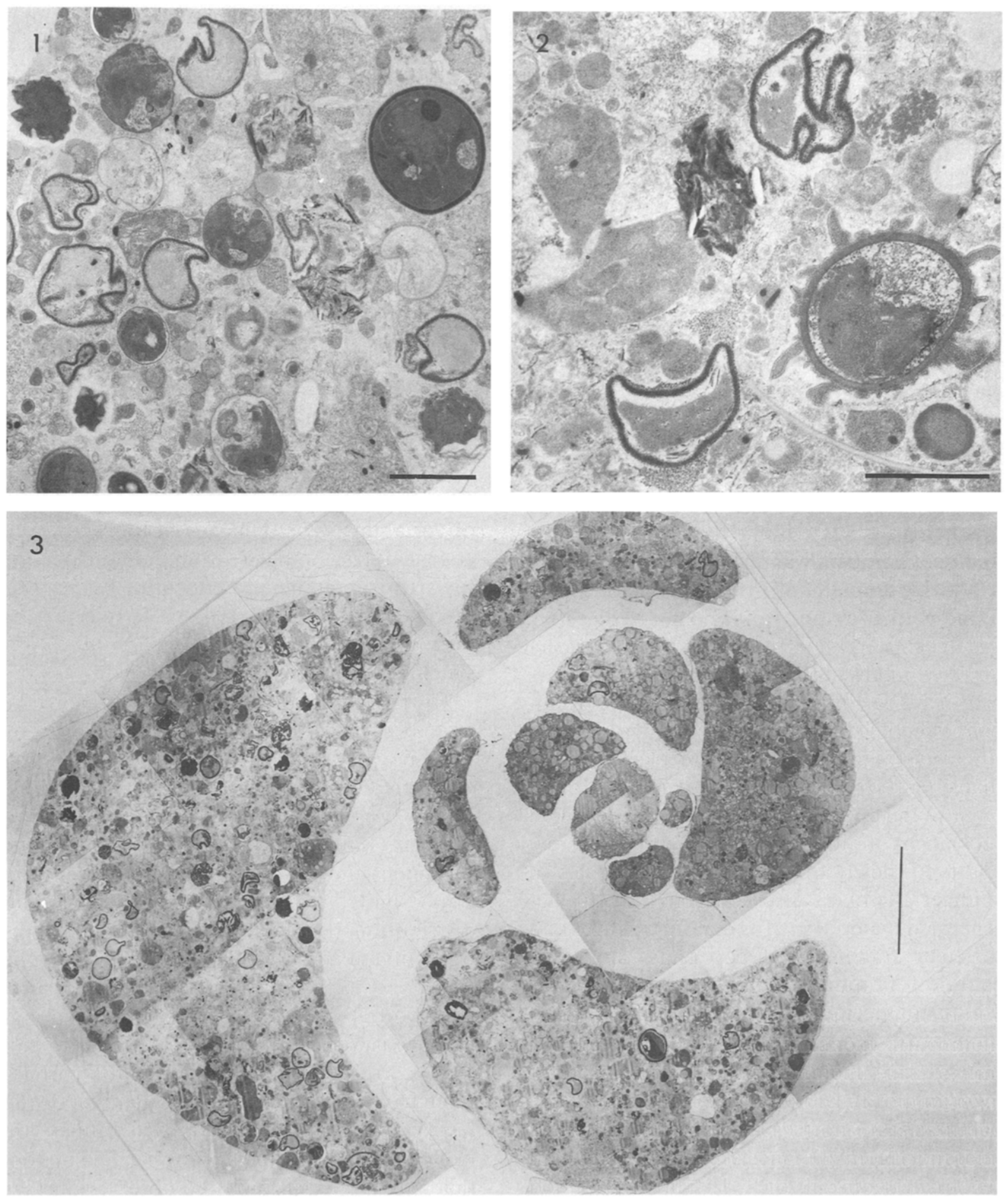
the inner wall came into contact during cutting of a fresh specimen, they stuck together (i.e. the inner portions were adhesive). A secondary adhesion of particles drifting in the bottom currents might be present on the outer surface of the tube. This could explain the finer texture in the youngest, uppermost portion of the tube to which particles had yet to be glued.

\section{Cytological characteristics}

A cross section of a decalcified test revealed pronounced differentiation of the cytoplasm in $M$. subrotunda (Plate II, 3). Numerous thecate and coccale algae are contained in food vacuoles of highly vacuolised areas of young chambers (Plate II, 1 and 2). The algae commonly still retained identifiable chloroplasts and reserve substances. The amount and volume of digestive vacuoles greatly decreased in older chambers and there the cytoplasm was much denser (Plate II, 3). Most of the volume in older chambers was occupied by lipid droplets with a diameter of 1 to $2 \mu \mathrm{m}$. Bacteria were found neither in the cytoplasm nor in digestive vacuoles. In Pyrgo rotalaria and Quinqueloculina seminula sampled from surface sediments near tube-building $M$. subrotunda, the dominant vacuole items were bacteria and minute siliceous fragments of thecate algae smaller than $1 \mu \mathrm{m}$ (Heeger, 1990). In all species found on or in the uppermost sediment layer, reserve substances of older chambers were only rarely observed; newly formed nutrient vacuoles in younger chambers also contained greatly degenerated material such as diatom frustules and cuticular fragments of copepods. However, benthic foraminifera sampled from the deep sea during periods of low food input tend to show hardly any food vacuoles or lipid vesicles (Heeger, 1990).

\section{Discussion}

\section{On the producer of the detritic cysts}

The ability to construct organic capsules surrounding the test was described by Rhum- bler (1936) for Miliolinella (Miliolina) subrotunda. According to Rhumbler, organic, detritic cysts with protruding tubes are commonly produced by epibenthic miliolids of different genera and species, providing shelter for the enclosed cytoplasm and a support for reaching the broadest possible area surrounding the specimen. Rhumbler (1936) pointed out that the construction of these detritic cysts is accompanied by a tendency towards a more rounded test shape and a reduced or even missing apertural tooth in the test of the miliolid producer. Indeed, some tests found on top of the tubes differ somewhat from the description of Miliolinella (Vermiculum) subrotunda (Montagu, 1803) in their possession of a more distinct or rounded periphery, but they perfectly resemble the chamber arrangement typical for $M$. subrotunda in transverse section. Obviously, the test form exhibits a large degree of variability. The tendency of this species to change during ontogeny from quinqueloculine towards triloculine and biloculine shapes was discussed by Haynes (1973). He rejected the view of other authors that $M$. subrotunda is a specific triloculine form.

Tube constructions somewhat resembling the structures described here are produced by benthic metazoans, raising the question whether or not tubes observed in biological studies are produced by metazoans or foraminiferans (Mattson and Cedhagen, 1989). If the specimens of $M$. subrotunda randomly settle on a tube built by another organism, a random distribution between the morphological features of the foraminiferal test and the tube would be expected. However, all measurements on the tube are significantly correlated with measurements of the associated test, and these correlations are as high as the correlations among measurements of the tube or the test, individually. Therefore, the tubes are likely formed by the organisms perched on top; this is suggested also by the observation that the tests are completely surrounded by the uppermost portions of the tube. 


\section{The elevated epibenthic habitat}

In shallow water, the detrital structures produced by Miliolinella spp., Cibicides lobatulus and Cibicides refulgens (Rhumbler, 1936; $\mathrm{Ny}$ holm, 1961; Alexander and DeLaca, 1987) surround the foraminiferal test. The resulting canopy of the agglutinated test extensions observed in C. refulgens are estimated to increase the volume of water available to suspension feeding by a factor of 10 to 20 , enhancing capture efficiency by factors of 2.5 and 6.1 for diatoms and bacteria, respectively (Alexander and DeLaca, 1987).

The unbranched tubiform and especially large construction, relative to test size, produced by $M$. subrotunda serves to raise the test far above the sediment surface. The test is lifted into the area of laminar flow and in the deep sea larger tubes (up to $6 \mathrm{~mm}$ total height) can reach the turbulent zone above the sediment surface. In bottom currents of only a few centimeters per second, this small distance of a few millimeters above the sediment surface is sufficient for optimal positioning of Saccorhiza ramosa for filter feeding (Altenbach et al., 1988 ). From the ultrastructural differentiations of food vacuoles (organic content) and the different physiological levels (reserve substance deposits) observed in the elevated epibenthic $M$. subrotunda and two species sampled from the surface sediments $(P$. rotalaria and $Q$. seminula), there is apparently an increase in the nuritional value of food derived from the lateral particle flow (see also Heeger, 1990; Altenbach et al., 1988).

Due to the small size of organic particles and their specific density very near to that of the surrounding fluid, a physical fractionation derived from the hydrodynamic activity in bottom currents should be of minor influence on the composition of this food source. However, as observed in capillary blood-vessels, small suspended particles with densities slightly higher than that of the surrounding fluid are displaced from a confining wall and consequently are concentrated at some distance from it; little information is available on this theme and we only can speculate on the possible influences on local food particle concentrations in the viscous sublayer of marine environments (Altenbach et al., 1988).

Increasing distance from the sediment surface will mainly result in an increase in the number of particles caught per time unit from the source of drifting suspended matter; this increase will be nearly linear within the viscous sublayer, and grow exponentially in the turbulent flow above. But based on the velocity profile, the expansion of turbulence will also increase the danger of being uprooted or broken (Altenbach et al., 1988). As a result, tubular test fragments of agglutinated epibenthic species with stiff test constructions protruding from the sediment surface are found redeposited and sorted in turbidite layers, and are more susceptible to entrainment and redeposition than species living on or in the surface sediments (Kaminski et al., 1988). The flexible tubes of $M$. subrotunda will be swayed, curved and pressed downward by the current. Depending on the frontal area exposed to the flow and the diameter of the protuberance, it can be stated that the higher the top, the worse are both the drag and the drag coefficient (Vogel, 1983 , p. 135). According to Vogel, protuberances with rounded tops and an edge smoothly tapering into the attachment surface improve stability and drag resistance, even for small protuberances and low currents (i.e. at more modest Reynolds numbers). Over a specific range of velocity, the broadened conical base provides an improved attachment and a reduction of the drag coefficient will result from passive reorientation of the flexible tube in proportion to the magnitude of flow velocity. In summary, from the broadened conical base on the sediment surface, up to the flexible tube 
and the covered, rounded test on top, the effects of drag should be considered in order to understand the observed construction. As $M$. subrotunda was found accompanied by living $S$. ramosa in our samples from the GreenlandNorwegian Sea, the near-bottom hydrodynamic environment in these locations seems suitable for both types of stiff or more flexible constructions.

Experimental feeding of foraminiferal assemblages with enriched plankton material on board of R.V. Meteor led to a marked response in benthic foraminifers (Linke, 1989; Heeger, 1990; Altenbach, 1992). This response was detected from uptake of the particle to excretion of undigestable remains in the cytoplasm (Heeger, 1990). Specimens of the elevated epibentic $M$. subrotunda produced a pronounced apertural plug a few hours after feeding. From the food offered, copepod muscle tissue and fresh phytoplankton cells were observed within the cytoplasm of $M$. subrotunda 3 days after food input. Similar contents within the nutrient vacuoles were observed in specimens from surface sediments (Quinqueloculina sp., Pyrgo sp.) five to six days after food input (Heeger, 1990). This gives a lag time of two to three days for the response of species living on, or in the uppermost sediments, in comparison to species adapted to feeding in the lateral particle flow. As this timelapse is similar to the period of food ingestion for species rapidly responding on a flux event (Altenbach, 1992), the tube-building of $M$. subrotunda may be derived to compete with other opportunists living at the sediment surface. Another reason to extend into water levels with higher currents during single stages of ontogeny (other than for feeding purposes) could be the release of reproductive products into the currents. However, none of the specimens studied showed the cytoplasmic differentiation characteristic of reproducing foraminifera; in addition, individuals of various sizes were found on top of the tubes, not only large adult forms.
Estimating the timespan for the production of a tube

In a broad range of environments in the Greenland-Norwegian Sea, $M$. subrotunda is a common member of foraminiferal biocoenoses lacking any cysts (Thies, 1991). It has also been reported living epizoically on bivalves (Haward and Haynes, 1976). The tubes and cysts observed in this species are only produced facultatively. Amphipods of the genus Dyopedos, some millimeters in length, can build a complete tube structure of several centimeters in length in only a few hours (Mattson and Cedhagen, 1989). As a way to take advantage of temporary opportunities, such as the sedimentation of a flux event, it must be assumed that construction and active feeding takes place within only a few days or weeks, as suggested by observed reaction times of other benthic foraminifers (Gooday and Turley, 1990; Altenbach, 1992). In this case a pronounced increase in biomass must take place in a short period of time to compensate for the energy invested in the construction of the tube.

Indeed, from the biometric data (Table 2) we find evidence for the assumption that the tube is built in a relatively short period of time. If the tubes were built through the entire ontogeny of the individuals, the basement would be built by the juvenile stage, and consequently might be expected to be small; but specimens with increasing test size also show increasing sizes in diameter and length of the conical base structure of the tube. The diameter of the tube would be expected to become enlarged with the stepwise increase of the test size by new chamber formation; but the average diameter of the tube remains constant from the top of the conical base of the tube to the base of the test. Accordingly, the foraminifer must rotate $180^{\circ}$ after each new chamber is formed to account for the upward positioning of the aperture observed in all specimens on top of the tubes. A secondary thickening of the tube could be the only alternative explanation 
for the observed correlations of biometric measurements; however, there is no evidence for such thickening from our investigations. Therefore, the production of the tube seems to take place in a relatively short period of time and its size is thus correlated with the test size of the individual that produced it.

\section{Acknowledgements}

We would like to thank masters and crews of R.V. Meteor, R.V. Polarstern and R.V. Poseidon for cooperation, and the Deutsche Forschungsgemeinschaft for their support in the Sonderforschungsbereich 313 at Kiel University, which contributes much for interdisciplinary studies. We greatly appreciate the exchange and the written communications with S. Zheng on samples of $M$. subrotunda, and the support of $\mathrm{H}$. Bender and C. Samtleben for the SEM work. B. Corliss, P. Dingle, M. Langer, J. Lipps and $\mathrm{R}$. Ross gave stimulating comments and made improvements on the manuscript. This is Contribution No. 107 of the SFB 313 at Kiel University.

\section{References}

Alexander, S.P. and DeLaca, T.E., 1987. Feeding adaptions of the foraminiferan Cibicides refulgens living epizoically and parasitically on the antarctic scallop Adamussium colbecki. Biol. Bull., 173: 136-159.

Altenbach, A.V., 1992. Short term process and patterns in the foraminiferal response to organic flux rates. In: G.J. van der Zwaan, F.J. Jorissen and W.J. Zachariasse (Editors), Approaches to Paleoproductivity Reconstructions. Mar. Micropaleontol., 19: 119-129.

Altenbach, A.V., Unsöld, G. and Walger, E., 1988. The hydrodynamic environment of Saccorhiza ramosa (Brady). Meyniana, 40: 119-132.

Gooday, A.J. and Turley, C.M., 1990. Responses by benthic organisms to inputs of organic material to the ocean floor: a review. Philos. Trans. R. Soc. London, Ser. A, 331: 119-138.

Haward, N.J.B. and Haynes, J.R., 1976. Chlamys oper- cularis (Linnaeus) as a mobile substrate for foraminifera. J. Foraminiferal Res., 6: 30-38.

Haynes, J.R., 1973. Cardigan Bay Recent Foraminifera. Bull. Br. Mus. (Nat. Hist. ), Zool., Suppl., 4, 245 pp.

Heeger, T., 1990. Elektronenmikroskopische Untersuchungen zur Ernährungsbiologie benthischer Foraminiferen. Ber. Sonderforschungsbereich 313, Univ. Kiel, 21: $1-139$.

Kaminski, M.A., Grassle, J.F. and Whitlatch, R.B., 1988. Life history and recolonisation among agglutinated Foraminifera in the Panama Basin. In: F.M. Gradstein and F. Rögl (Editors), Second Workshop on Agglutinated Foraminifera. (Vienna, 1986.) Abh. Geol. Bundesanst., 41: 229-243.

Linke, P., 1989. Lebendbeobachtungen und Untersuchungen des Energiestoffwechsels benthischer Foraminiferen aus dem Europäischen Nordmeer. Ber. Sonderforschungsbereich 313,18:1-123.

Lipps, J.H., 1983. Biotic interactions in benthic foraminifera. In: M.J.S. Tevesz and P.L. McCall (Editors), Biotic Interactions in Recent and Fossil Benthic Communities. Plenum, New York, pp. 331-376.

Lutze, G.F. and Altenbach, A.V., 1988. Rupertina stabilis (Wallich), a highly adapted, suspension feeding foraminifer. Meyniana, 40: 55-69.

Mattson, S. and Cedhagen, T., 1989. Aspects of the behavior of Dyopedos monacanthus (Metzger) and $D$. porrectus Bate, with comparative notes on Dulichia tuberculata Boeck (Crustacea: Amphipoda: Podoceridae ). J. Exp. Mar. Biol. Ecol., 127: 253-272.

Montagu, G., 1803. Testacea Britannica, or Natural History of British Shells Marine, Land and Fresh Water, Including the Most Minute: Systematically Arranged and Embellished with Figures. Hollis, Romsey, England, $606 \mathrm{pp}$.

Nyholm, K.-G., 1961. Morphogenesis and biology of the foraminifer Cibicides lobatulus. Zool. Bidr. Uppsala, 33: $157-192$.

Rhumbler, L., 1936. Foraminiferen der Kieler Bucht II. Kiel. Meeresforsch., 1: 179-242.

Thies, A., 1991. Die Benthos-Foraminiferen im Europäischen Nordmeer. Ber. Sonderforschungsbereich 313, Univ. Kiel, 31: 1-97.

Thomsen, L., 1991. Treatment and splitting of samples for bacteria and meiofauna biomass determinations by means of a semi-automatic image analysis system. Mar. Ecol. Prog. Ser., 71: 301-306.

Vogel, S., 1983. Life in Moving Fluids. Princeton Univ. Press, NJ, $352 \mathrm{pp}$.

Von Bertalanffy, L., 1960. Principles and theory of growth. In: W.W. Nowinski (Editor), Fundamental Aspects of Normal and Malignant Growth. Elsevier, Amsterdam, pp. 137-259. 